\title{
The Realization of Address Terms in \\ Modern Persian in Iran: \\ A Sociolinguistic Study*
}

\author{
Mohammad Aliakbari/Arman Toni (Ilam University)
}

\begin{abstract}
As an important feature of interface between language and society, address terms can provide valuable sociolinguistic information about the interlocutors, their relationship and their circumstances. As a result, in the past few decades address terms in different languages have been studied from different angles and with varying focus. In line with those studies this article focuses on identifying different types of addressing terminology that Persian interlocutors may use in different contexts. Personal names, general and occupation titles, kinship related terms, religious oriented expressions, honorifics, terms of intimacy, personal pronouns, descriptive phrases and employing greetings or attention getters to avoid address terms were found to be the possible categories for Persian addressers' choice. The study also reveals that Persian language is rich enough in this respect and that an artful skill is required for Persian speakers to make an accurate and proper use of the vast range of choices for addressing individuals in various contexts. In addition to account for the abandonment of certain socioeconomic-referenced terms, the study also shows a number of culture-specific address terms which may have no equivalent in English.
\end{abstract}

\section{$1 \quad$ Introduction}

Establishing social relationship between individuals is perhaps the first step to every communicative event. To do so, people may choose different techniques to open, further, maintain, or close conversations. One important issue in studying communication is to learn how individuals manage to open conversations or how people may address one another in a given language.

Forms of address have their roots in sociocultural context of a society. Oyetade (1995) defines address terms as words or expressions used in interactive, dyadic and face-to-face situations to designate the person being talked to. Leech (1999) considers that terms of address are an important formulaic verbal behavior well recognized in the sociolinguistic literature as they signal transactional, interpersonal and deictic ramifications in human relationships. To Afful $\left(2006^{\mathrm{a}}\right)$ "terms of address constitute an important part of verbal behavior through which the behavior, norms and practices of a society can be identified". Other scholars also consider the study of address terms a fruitful field for sociolinguistics due to the fact that it shows how interpersonal relationships can be socially and strategically constructed (Fitch 1991, Morford 1997).

\footnotetext{
* The authors would like to express their sincere gratitude to two anonymous referees for their valuable comments and scholarly contribution to the first version of the article.
} 
Address terms in different speech communities are worth study. They are likely to be different because different languages have different linguistic resources to express what is culturally permissible and meaningful. Moreover, speakers use address terms to negotiate or transform a cultural system (Fitch 1991, Morford 1997) and issues such as sexuality, age, ethnicity and religion can also be inferred and realized from address terms (Afful 2006 ${ }^{\mathrm{a}}$ ).

Though many investigations have been conducted to study address terms in different languages, Persian language has received tertiary attention for rigorous studies. As a result, the present study is an attempt to investigate the choice of address terms by Iranian Persian speakers.

\section{Conceptual Framework and Review of Related Literature}

Throughout the past decades, with a considerable depth and varying issues sociolinguists have been deeply concerned with exploring different dimensions in selection of address terms. As a classic study in sociolinguistics, Brown and Gilman (1960) pronominal address system highlighted the semantic power and solidarity in relation to address terms. Since then good numbers of studies, with much broader scope and depth, have emerged. Brown and Ford (1964) focused on intimacy and status, Hymes (1967) studied social distance, Pride (1971) approached formality and informality and Moles (1974) explored confidence and respect. Consequent studies on address terms focused on other languages and support the view that address forms identify and construct cultural beliefs (Evans-Pritchard 1964, Manjulakshi 2004, Koul 1995 among others).

Mehrotar (1981) describes the non-kin forms of address in Hindi in relation to sociocultural setting of dyads using them. He notes that address forms embody a crucial stage in face-toface interaction and represent a special aspect of relational language. "They serve not merely as a bridge between the individuals but also as a kind of 'emotional capital'; which can be invested and manipulated in order to achieve a specific result." He further asserts that the differential usage of address terms has been institutionalized as a means of defining and affirming both identity and status of the speaker and the addressee. "In fact, a good deal of information regarding the social structure and psychological make up of the addressing dyad can be inferred from an examination of these verbal art forms in their two indispensable and interrelated dimensions-linguistic and sociolinguistic."

Similarly, Hudson (1980) points out that an important dimension of variation in address terms has to do with cultural patterns that hold for some particular population in general due to their social values, beliefs and customs.

Keshavarz (1988) conducted a study of the forms of address in post revolutionary Iran. In search for the political function of address terms, he reports that the revolution in Iran which led to the flight of the Shah resulted in the choice of address terms indicating solidarity and the need to express solidarity led to greater use of terms like 'bother' and 'sister'.

Exploring Kashmiri language, Koul (1995) points out that a study of terms of address in any language plays a very important role in socio-linguistic research. He further continues that these terms are determined by certain factors as social structure, cultural pattern and geographical setting. "The role of human beings varies in a particular society according to the requirements of that society [...] the modes of address are determined by socio-economic status, literacy level, caste, age and sex." He continues that the selection of modes of address is influenced by different historical and social factors as well.

Manjulakshi (2004) also notes that terms and modes of address are important in any society for purposes of identification and expression of ideas. To her, the use of these terms depends upon the social rank, age, and the sex of the persons involved in any communicative situation. 
"The relationship that exists or is perceived to exist between persons addressing and persons addressed to come to control and guide the selection and use of terms and related modes of delivery."

Wardhaugh (2006) also notes that a variety of social factors usually governs our choices of terms. Among these social factors are the particular occasion, the social status or rank of the other, sex, age, family relationships, occupational hierarchy, transactional status, such as a doctor-patient relationship or priest-penitent, race, and the degree of intimacy.

As far as the scope of the studies is concerned Afful $\left(2006^{\mathrm{a}}\right)$ notes that studies in sociolinguistics used to be limited to domestic or familial settings. He also thinks that "more recently, studies of address terms (sometimes aided by discourse analysis) are beginning to make forays into other social processes and practices such as politics and religion suggesting the vitality of address terms". He claimed that the influence of Westernism and modernism was reflected in the use of personal names and catch phrases. "With differing levels of frequency and saliency, the use of these terms was dictated by sociocultural factors such as gender, status, age and relationship of interactants as well as pragmatic factors" (ibid). He further asserts that the findings of address term studies have implications for theory, intercultural communication and further research.

In a study of bilingual creativity in Chinese English, Zhang (2002) stresses the importance of address term studies and specifies that these terms play an important role in conveying cultural messages, especially with respect to the status of interlocutors and power relation between them.

In another study, Afful $\left(2006^{\mathrm{b}}\right)$ makes a distinction between 'address terms' and 'reference terms' and uses the former as the linguistic expression by which an addresser designates an addressee in a face-to-face encounter. With reference to the social functions of address terms, Afful $\left(2006^{\mathrm{b}}\right)$ also notes that sociolinguistic studies on address terms tend to show that they are contingent on a number of factors such as socioeconomic status, age, sex, the relationship that exists between interlocutors and the domains of a communicative encounter.

\section{Classification Scheme}

With respect to the long history of Persian language, it is right to expect a wide range of address terms to account for the diverse and multicultural nature of the Iranian communities. It is also true that due to inherent differences among languages, researchers may adopt different classification schemes.

In a relatively sophisticated study of address terms, Mehrotar (1981) elaborates on nine categories of names, honorifics, titles, situation factors, multiple uses of address forms, greeting, invocation, addressing pets and avoidance of address term as possible classification of address terms in Hindi.

Studying the variety of relationship among participants in Columbia, Fitch (1998) identifies five categories of address terms: second-person pronouns, proper names, kinship terms, titles, nicknames and adjectival terms.

Studying non-kinship address terms in Akan, Afful $\left(2006^{\mathrm{b}}\right)$ classified eight categories that constituted the non-kinship linguistic repertoire used addressively by Amamoma residents as personal names, titles, catch phrases (CPs), zero address forms, descriptive phrases, attention getters, occupational terms and pronouns. In another project, using observation as the main research tool corroborated by interview and introspection, Afful $\left(2006^{\mathrm{a}}\right)$ refers to nine principal terms of address. 
In an attempt to describe the modes of address and address terms in Kannada language spoken in Mysore District in India, Manjulakshi (2004) considers nine types of address terms as; Caste Name, Names by which the exalted status of individuals are revealed or implied, Personal name, Kinship term, Professional term, Professional-Names for exaltation, Personal name-kinship term, Personal name-professional term, and Non-respectable term.

The studies noted so far convincingly support the fact that a comprehensive identification and coverage of address terms in a language requires a clear classification scheme. They also seem to accept variation in classification of address terms to represent cultural and social differences of the users.

After observing variant kinds of interactions, the observed address terms were classified under ten categories: personal names, titles, religious-oriented terms, occupation-bound terms, kinship or family/relative terms, honorifics and terms of formality, terms of intimacy, personal pronouns, descriptive phrases, and zero address terms. The reason for developing this classification was that it can display the common Persian address terms more clearly according to its social and cultural conditions. However, it should be mentioned that in almost all groups, different gender bound terms are used for male and female addressees.

\section{The Study}

In line with the above-mentioned theoretical and research based views, this paper attempts to present and, to some extent, explain the linguistic resources available to Persian addressers. In so doing, the study intended to extract and categorize the range of address terms which Persian-speaking interlocutors use in different circumstances. To capture a corpus of address terms, the researchers made observations of the terms which Iranian male and female interlocutors use to call their recipients in different contexts. Deliberate attention was also paid to ensure the exploration of the common Persian address terms used by speakers in different ranges of age as well as different occupations.

\subsection{Personal Names}

In Persian addressing a person by personal name may happen with the following possibilities.

1. by first name (FN), e.g., حسن /Hassan/,

2. by last name (LN), e.g., احمدى/Ahmadi/,

3. by full formal name, i.e., first and last name (FLN), e.g., حسن احمدى/Hassan Ahmadi/.

Iranians have first and family name but no middle name. Different from western cultures, calling people by first or given name is not so common in Persian. It is not considered respectful to call people by FN. Acceptable cases of FN calling may only be limited to elders addressing the young people, or teenagers calling each other. Or in very formal settings with observable status differences like schools or army, a teacher or an officer may call students or soldiers by full name. As a result, even intimate friends are expected to add an honorific or a term of respect like آقان /âghâ/ (Mr.) or آقان احمد /ân/ (dear) before or after the names as Ahmad/, احمد آقا /Ahmad âghâ/ (Mr. Ahmad) or رضا جان/Reza jân/ (dear Reza). Such expressions often result in more courtesy and formality in interlocutors' speech. Further explanation of this trend is provided in the sections that follow.

\subsection{Title Terms}

Title, here, refers to given initials of individuals in order to show their social ranks, or gender in different circumstances. Below, are the gender-specific titles which Persian male and female speakers make use of in their conversations. 
One may call his male addressee by:

- General Title (GT), such as آقآ إِسر /âghâ/ (Mr. آقا /â pesar/ (Mr. boy),

- GT plus FN, like احمد آقا /Ahmad âghâ/ (Mr. Ahmad),

- GT plus LN, like آقاى محمدى /âghâye Mohamadi/ (Mr. Mohamadi),

- Or a combination of all of these, e.g., آقاى احمد محمدى/âghâye Ahmad Mohamadi/ (Mr. Ahmad Mohamadi).

Persian females are addressed in the same way, but by different title terms. Among GTs there are: خانم/khânom/ (Mrs. or Miss), دختر خانم/dokhtar khânom/ (Miss girl). An example of a combination of GT and FN can be مريم خانم /Maryam khânom/ (Mrs. Maryam), GT and LN, خانم/R / خانم مريم محدى /khânom Mohamadi/ (Mrs. Mohamadi), and GT, FN and LNânom Maryam Mohamadi/ (Mrs. Maryam Mohamadi).

As can be observed from examples, different from some English speaking communities, it is normal in Persian to address someone with both title and first name.

\subsection{Religious Address Terms}

Religious orientation has left a special impact on address terms in Persian language. One particular way of addressing refers to pilgrimages of three holy shrines: Mecca, Karbala and Mashhad. Accordingly, as a sign of respect in religious situations, or to convey such tendency, it is common to call somebody you guess has been to those holy places, as /hâji/, /karbalâii/ or /mashhadi/. In such cases when a person who has been to the city of Mecca and has done the special religious ceremony of حج/haj/, may be addressed by the terms حاجى/hâji/ or حاجيه خانم/hâjieh khânom/ for women. In the same way, the pilgrim to Karbalâ in Iraq is called كربلاجيى/karbalâii/ or كربلايى احمد/karbalâii Ahmad/, and the pilgrim to Mashhad in Iran is addressed by the terms مشهى /mashhadi/ مشهدى على /mashhadi Ali/.

One more case of religious oriented address terms is the use of the titles سيد/sayed/ (Male descendant of Holly Imams) and سيده/sayede/ (Female descendant of Holly Imams) for certain males and females whose pedigree goes back to Holy Imams. These terms can be used in isolation or with or without first name, last name or full formal names and as can be inferred none of these terms seem to have exact English equivalents.

The use of these address terms is also gender bound. More examples of this class of address terms are برادر/barâdar/ (brother) and خواهر/khâhar/ (sister). In spite of the fact that the terms "brother" or "sister" are used in some languages as an indirect influence of Russian MarxistLeninistic ideology, our observation of the use of these terms in modern Persian confirms Keshavarz (1988) interpretation. Their frequent use signify Islamic-post revolutionary attitude and ideology of their users.

\subsection{Occupation-Bound Terms}

Occupation-bound terms are very common in Persian address system. The number of address terms which refer to particular careers or occupational status is probably as many as the occupations themselves. One could address his or her recipient by:

- Only Job Title (JT), e.g., دكتر /doktor/ (doctor), مهنس /mohandes/ (engineer), سردار /sardâr/ (general), امير /amir/

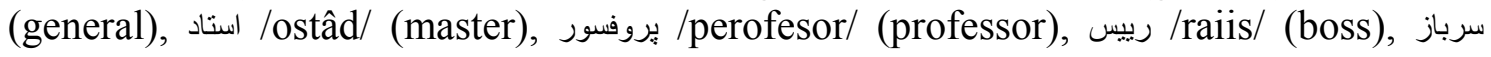
/sarbâz/ (pirate). 
- A combination of GT and JT, e.g., آقاى دهنس /kâhghâye mohandes/ (Mr. engineer), آقاى رييس جمهور / آناى /âghâye raiis-jomhoor/ (Mr. president).

- A combination of $\mathbf{J T}$ and $\mathbf{L N}$, e.g., سكتر محمى /doktor Mohamadi/ (Dr. Mohamadi), سردار محمدى /sardâr Mohamadi/ (general Mohamadi).

- A combination of GT, JT and LN, e.g., آقاى دكتر محمدى /âghâye doktor Mohamadi/ (Mr. Dr. Mohamadi).

- A combination of GT, JT, and FLN, e.g., آقاى مهنس احمد محمدى /âghâye mohandes Ahmad Mohamadi/ (Mr. engineer Ahmad Mohamadi).

Compared to some casual societies, senses of formality is clearly observed in Persian address terms. Moreover, as another interesting feature of Persian language, people may use different terms for job titles (JT) while addressing the same occupation to reveal their degree of respect or to make themselves superior, equal or inferior in relation to the addressee. For example a driver may be called راننده/sânandeh/ or شوفر/shoofer/and a musician may be called نوازنده/. /navâzandeh/ or مطرب/motreb/.

\subsection{Kinship or Family/Relative Terms}

A good number of Persian address terms indicate the family relationships among individuals. One may call his father by the following terms: بابا /bâbâ/ (dad), بابه /pedar/ (father), آقاجان/âgha jân/ (dear Mr.), بابايى /bâbâii/ (daddy), باباجان /bâbâ jân/ (dear dad);

Mothers may be addressed by: مامان /mâmân/ (mom), مادر /mâdar/ (mother), مامانى /mâmâni/ (mommy), مامان جان /mâmân jân/ (dear mommy), etc.

Brothers are called برادر/barâdar/, داداش /dâdâsh/ or داداشى /dâdâshi/ (brother), خان داداش /khân dâdâsh/ (great brother), and also by their FN.

Sisters are called هواهر/khâhar/, همشيره / هبر /hamshireh/ (sister), and also by their FN.

It deserves notice that in Persian there are two words for 'aunt' and two for 'uncle' which show their relationship to one's mother or father. As for the cousins, Persian speakers use both gender referenced term and a kinship term to call a cousin. Thus, one's aunt is called /ammeh/, عمه جان /ammeh jân/ and عمان /ammeh khânom/, if she is his father's sister, or خانم اله /khâleh/, خاله جان خان خانم /khâleh jân/ خانه /khâleh khânom/, if she is his mother's sister.

Uncles, i.e. father's brother, are called عمو/amoo/, عمو جان/amoo jân/, خان عمو//khân amoo/, and

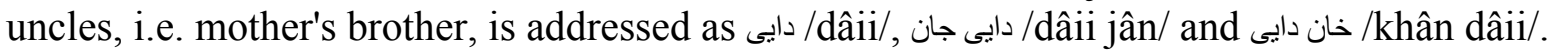

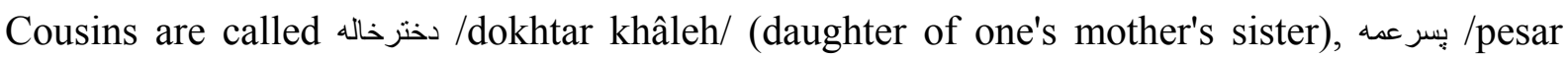
ammeh/ (son of father's sister), or /بّر دايى / (son of mother's bother).

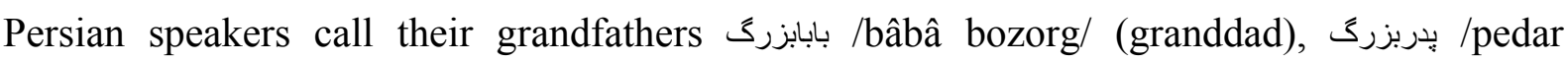
bozorg/ (grandfather), بپرجان /pedar jân/ , جانان /âghâ jân/, etc.;

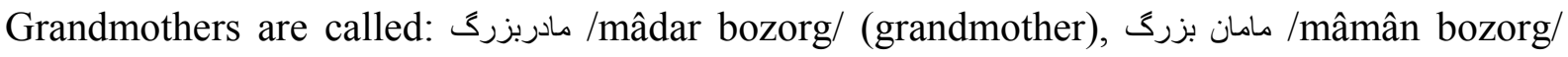

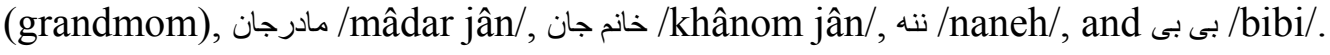

One's daughter-in-law, i.e. son's wife, is addressed as عروس /aroos/ (bride). 
A very interesting characteristic of Persian speakers is in the use address forms in addressing a recipient with addressers title not the addressee's. The following example clarifies this reverse addressing possibility:

A man to his son: "بابايى، در رو باز كن." "Daddy, open the door." More examples of reverse addressing are with using the terms خاله/khâleh/ or /ammeh/ (aunt) in addressing one's niece or nephew e.g. the aunt calls a niece 'auntie do me a favor'.

Another interesting and probably special addressing strategy is the use of family or relative terms for non relative addressees, as if they are calling a family member or a relative. Some examples are as follows:

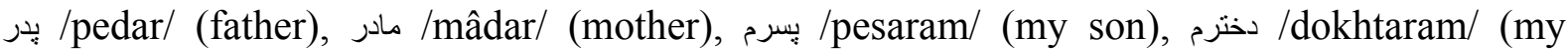

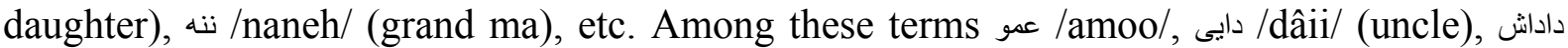
/dâdâsh/ (brother), are mostly used by male speakers when calling their male addressees. The terms هشيره / خواهر /hamshireh/ آبجى /âbji/ (sister), are used when addressing a female recipient.

\subsection{Honorifics or Terms of Formality}

Perhaps Mehrotar (1981) is right in pointing out that the use of honorifics is a common trait of most oriental languages. They are used when a speaker wishes to show respect to the addressees. In Persian, as in other oriental languages like Arabic, Turkish, Urdu, etc. there are numerous types of appositional expressions, which could be used in order to honor or dignify the addressed person. This honorific or honor names include a collection of religious, cultural, occupational, ideological as well as pet names. Such terms may be used in several forms; before, after, with or without the name of the addressee.

In order to put more formality into speech, Persian speakers enjoy a good number of address terms. Some examples are قربان/ghorbân/ (sir), جناب /jenâb/ (sir) and سركار/sarkâr/ (lady).

The first addressing قربان /ghorbân/ is used alone, whereas جناب /jenâb/ and سركار /sarkâr/, are possible to be used alone, or with titles and occupation-bound address terms depending on the جناب سروان /jenâb sarvân/ ( جناب احمد محمى /jir captain), with FN and LN, as Ahmad Mohamadi/ (sir Ahmad Mohamadi), or with GT, FN and LN, as in سركار خانم مريم محمدى /sarkâr khânom Maryam Mohamadi/ (lady Mrs. Maryam Mohamadi).

Still there is one more possibility to use these terms together with GT, JT, FN, and LN, as in جناب آقاى استاد احمد محمدى /jenâb âghâye ostâd Ahmad Mohamadi/ (sir Mr. professor Ahmad Mohamadi).

Evident sociopolitical function of address terms can be observed with the use of honorifics in modern Persian. In post revolutionary Iran and after the fall of the monarchy, certain types of address terms, especially honorifics, led to the disfavor and abandonment or are presently non-frequent. Terms like شاهزاده/Shâhzadeh/ (prince or princess), اعليحضرت /alâhazrat/ (his majesty), عليا حضرت /oliâ hazrat/ (her majesty) and jenâb/ (your majesty) are just a few examples.

\subsection{Terms of Intimacy}

Given that Persian speakers bear considerable attention to the formality of addressing in speech, there are still situations where intimate colleagues address partners with more friendly and more amiable tone. By intimacy we refer to situations where the speaker treats the listener as a member of an in-group, a friend or a person whose wants and personality traits are known and liked. Earlier in this article conditions for using first name, last name and full names in 
intimate modes were specified. In addition to those possibilities, there are more options through which Persian speakers address their intimate partners.

One may address his colleague by:

- Nicknames, e.g., حسنى /Hassani/ (used for Hassan),

- Abbreviated first name (AFN), e.g., مد /Mamad/ (used for Mohamad),

- Pet names, e.g., عزيزم /azizam/ (my dear), خانم خانما /golam/ (my flower), خلم /khânom khânoma/ (beauty Miss).

In using nicknames in Persian, age, status and degree of intimacy are highly observed. Young children or school boys and girls may be addressed by nickname by parents, relatives, classmates and close friends. Grandmas and grandpas may also call their grandchildren by nickname to express their affection.

Persian speakers also use terms indicating signs of love, in order to show a close relationship with their listener, e.g., احمد جان /Ahmad jân/ (dear Ahmad).

There are still some specific address terms in Persian which are more or less used in situations where there is a very intimate relation between the two parties, such as كوجولو/koochooloo/

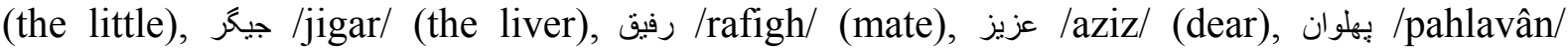
(champion), ارباب /arbâb/ (lord), etc.

\subsection{Personal Pronouns}

Persian language provides the speakers with the possibility to consider solidarity or power in addressing the other side with pronouns. They can call the addressee تو/tow/ (second person singular 'you') or شما/shomâ/ (second person plural 'you'). Often the plural you is used for a singular person to express much respect. Still one more respectful possibility is the use of plural 'you' with plural verb for a single addressee. In even more formal conditions terms such as جناب عالى /jenâb âli/ (your excellency) are used instead of شما /shomâ/ to treat the addressee with deference. To call or talk about the third person, Persian speakers may choose $9 / 00 /$ or ايثان /ishân/ for 'he' and 'she'. In case of concern for more solidarity they may also use the pronoun with plural verb to show greater respect to the addressees.

\subsection{Descriptive Phrases}

In addition to categories discussed so far, Persian interlocutors may use descriptive phrases as courtesy expressions to address others. Terms like آقاى عزيز /âghaye aziz/ (dear sir), خانم محترم /

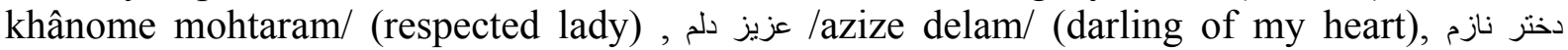
/dokhtare nâzam/ (my lovely girl) , خوشتيب: /khoshtip/ (handsom person) and بر بـر /gol pesar/ (good boy), are representative examples. These address terms may have $\mathrm{N}+\mathrm{ADJ}, \mathrm{N}+\mathrm{N}$, $\mathrm{ADJ}+\mathrm{N}, \mathrm{N}+$ possessive pr. $+\mathrm{N}$ and ADJ structure.

\subsection{Zero Address Terms}

Similar to Wardhaugh (2006) evaluation of English, when a Persian addresser is in doubt as to how address people s/he can actually avoid the difficulty by not using any term. Instead s/he may use attention getters or greetings.

As a common strategy to start a polite conversation, addressers may use attention getters to capture the attention of the recipient by saying بنشخيد /bebakhshid/ (excuse me), or معذر خوام /mazerat mikhâm/ (pardon me).

Alternatively, addressors may use grettings like سلام/salâm/ (hello) or صبح بخير /sobh bekheyr/ (good morning). 
Also as a deliberate act of avoidance of respectful terms to show anger or annoyance, addressors may prefer not to use address terms.

\section{$5 \quad$ Discussion and conclusion}

With respect to the observations of this study, the following points could be stressed: The attempt of the authors concerning categorization of the expressions in Modern Persian can be regarded as a pioneering effort to demonstrate the vast lingual potentiality of this language regarding multiplicity of interlocutory expressions on the one hand and the changeability and enrichment of these terms especially during the last three decades on the other. Thus the major intention in conducting the present work was to draw the general overall scheme of address terms that Iranian addressers might use to call their addressees.

The reason that the study developed ten categories of address terms in Persian language by no means supports the equivalence of the importance and frequency of the categories. Each category has its special usage for particular people and under certain conditions.

The abundance and the frequency of the application of honorifics in Persian language reveal the importance of courtesy in this language. It sounds that courteous and humble interaction is a striking feature of Persian address system. It also shows that Persian speakers are very careful about their face work.

Another distinctive feature of Persian is revealed in the use of kinship address terms. Persian is found to be very dependent on the family relations and this is especially notable in reverse addressing or using kinships for non-relatives.

Restrictions in the use of personal names and pronominal on the one hand and the tendency to use general and occupational titles, honorifics and terms of formality make it certain that the sense of formality is also another striking feature of Persian culture and language in general and address terms in particular.

Developing new terms and banding some others over time which is the characteristic of dynamic languages show that Persian language is dynamic enough to comply with the sociocultural changes in its speech communities.

To address one another, Persian interlocutors are likely to make use of different techniques. This open variety provides the Persian speakers with an extensive range of terms to address the recipients. Employment of a proper address term is affected by factors as age, gender, personality, social status, religious orientation, family relationship, the degree of respect, familiarity, formality and intimacy between the interlocutors.

One more point which indirectly accounts for the long history of Persian language and its interaction with other cultures is the existence of loanwords from other languages. As a result, Persian speakers may use terms from other relevant oriental languages like Arabic, Turkish, خانم آقا /khânom/ (Ms), and خان/khân/ (Mr., your Excellence) are examples of these loan vocabularies which are frequently used in Persian.

In general, the overall examination of the address terms provided in this article makes it clear that Persian address terms are gender sensitive, relatively formal and culturally, socially and politically loaded. Moreover, the stress in using honorifics, the special employment of kinship terms, the development of religious terms and the abandonment of the terms related to aristocracy stand for sociocultural and sociopolitical function of the address terms in modern Persian.

Finally it worths mentioning that due to the limits for the size of an article, this paper sufficed to present typical examples for each category. The inclusive list of the options which makes 
proper selection relatively artful is almost endless. Therefore, further research seems to be required to explore the conditions under which different categories are used. Determination of factors affecting the use of particular terms and explanation of the reasons for choosing one or the other can be new grounds for further research and studies.

\section{References}

Afful, Joseph B. A. $\left(2006^{\mathrm{a}}\right)$ : "Address terms among university students in Ghana. A case Study". Journal of Language and Intercultural Communication 6, 1: 76-91.

Afful, Joseph B. A. $\left(2006^{b}\right)$ : "Non-kinship address terms in Akan. A sociolinguistic study of language use in Ghana". Journal of Multilingual and Multicultural Development 27, 4: 275-289.

Brown, Roger/Gilman, Albert (1960): "The pronouns of power and solidarity". In: Sebeoki, Thomas A. (ed.): Style in language. Cambridge, MA: 253-276.

Brown, Roger/Ford, Marguerite (1964): "Address in American English". In: Hymes, Dell H. (ed.): Language in culture and society. New York: 234-244.

Evans-Pritchard, Edward E. (1964): "Nuer modes of address". In: Hymes, Dell H. (ed.): Language in culture and society. New York: 221-227.

Fitch, Kristine L. (1991): "The interplay of linguistic universals and cultural knowledge in personal address. Columbian Madre terms". Communication Monographs 58: 254-272.

Fitch, Kristine L. (1998): Speaking Relationally: Culture, Communication, and Interpersonal Connection. New York: Guilford.

Hudson, Richard A. (1980): Sociolinguistics. New York.

Hymes, Dell H. (1967): "Models of interaction of language and social setting". Journal of Social Issues 23, 2: 8-28.

Keshavarz, Mohammad Hossein (1988): "Forms of address in post-revolutionary Iranian Persian. A sociolinguistic analysis". Language in Society 17: 565-575.

Koul, Omkar Nath (1995): "Personal Names in Kashmiri". In: Koul, Omkar N. (ed.) Sociolinguistics. South Asian Perspectives. New Delhi.

Leech, Geoffrey (1999): "The distribution and function of vocatives in American and British English conversation". In: Hasselgard, Hilde/Oksefjell, Signe (eds.): Out of Corpora. Studies in honor of Stig Johansson. Amsterdam: 107-118.

Manjulakshi, L. (2004): Modes of address in Kannada: A sociolinguistic study of language use in Mysore District. Available at: http://www.languageinindia.com/sep2004/ manjulakshitermsofaddress 1.html (accessed September 2008).

Moles, Jerry A. (1974): "Decisions and variability. The usage of address terms pronouns and languages by Quechua-Spanish bilinguals in Peru". Anthropological linguistics 16, 9: 442463.

Morford, Janett (1997): "Social indexicality in French pronominal address". Journal of Linguistic Anthropology 7: 3-37.

Oyetade, Solomon Oluwole (1995): "A sociolinguistic analysis of address forms in Yoruba". Language in Society 24: 515-535.

Pride, John B. (1971): Formal and informal language. An inaugural address. Wellington.

Wardhaugh, Ronald (2006): An introduction to sociolinguistics. $5^{\text {th }}$ ed. Oxford.

Zhang, Hang (2002): "Bilingual creativity in Chinese English. Ha Jin's in the pond". World Englishes 21, 2: 305-315. 